\title{
Experimental Investigation on Size Effect in Shear of High-Strength Concrete Beams
}

\author{
Tavio $^{1}$
}

\begin{abstract}
In this paper, an experimental program on the size effect in high-strength reinforced concrete beams is described. A total of 18 deep and slender specimens with effective depth $d$ ranging from 200 to 700 $\mathrm{mm}$ and shear span $a$ ranging from 400 to $2450 \mathrm{~mm}$ were tested to failure under two-point symmetric top loading. Test variables were shear span to effective depth ratio $a / d$, web reinforcement percentage and the effective depth $d$. The compressive cylinder strengths $f_{c}^{1}$ of the beams vary from 75 to $104 \mathrm{MPa}$. The beams had the main steel ratio of 3.98 percent. Test results reveal that the ultimate shear stress is size dependent. Besides the shear span to effective depth ratio $a / d$, the effective depth $d$ also has a significant influence on the failure mode and the ultimate shear stress; larger deep beams are more brittle in comparison with smaller ones. The 18 test results are then compared with predictions from the current ACI Code, Zsutty's equation, Bazant's method, and Strutand-Tie model. Comparison study shows that while the safety of the ACI Code and Zsutty's equation reduces for larger concrete beams, Bazant's equation predicts well the trend on the influence of effective depth $d$ in highstrength concrete beams. The Strut-and-Tie model can predict the trend on the influence of effective depth in high-strength concrete deep beams, but overestimates the shear capacities of the beams.
\end{abstract}

Keywords - High-strength concrete; Building codes; Cracking; Web reinforcement; Effective depth; Size effect; Shear strength.

\section{INTRODUCTION}

$\mathrm{T}$ he first systematic and extensive test programme on size effect was carried out by Kani [1]. He pointed out that test specimens used in laboratory experiments with depths ranging from 250 to $400 \mathrm{~mm}$ were considerably smaller than actual structural members. Kani further demonstrated that the safety factor for the large beams could be about 40 percent lower than the geometrically similar smaller beams. From Kani's tests, it has been established that size effect exists in shear-loaded slender beams. The experimental information on the size effect is very scarce and most beams reported were slender beams with shear span to effective depth ratio $a / d$ exceeding 2.5 . The investigations of size effect of normal concrete deep beams were reported by Tan and $\mathrm{Lu} \mathrm{[2]} \mathrm{and} \mathrm{Walraven} \mathrm{and}$ Lehwalter [3]. For the investigation by Taylor [4] considered that the mechanism of aggregate interlock contributed substantially to the shear capacity, while keeping the particle size constant and increasing the

Manuscript received September 9, 2008; Revised February 3, 2009

${ }^{1}$ Tavio is with Department of Civil Engineering, FTSP, Institut Teknologi Sepuluh Nopember, Surabaya, INDONESIA.

Email: tavio_w@yahoo.com beam size should lead to decrease of the aggregate interlock contribution. According to Taylor's analysis, the size effect would be impossible to occur in lightweight concrete and high-strength concrete beams. This is because in these beams the cracks go through the aggregates instead of going around them. His size effect theory, however, was unconfirmed by the later tests. In 1978, Walraven [5] tested two series of three beams each, in which the size effect in lightweight and normal weigh concrete specimens were compared. The results showed a very pronounced size effect occurred in lightweight concrete beams. Bazant and Kim [6] and Bazant and Sun [7] then applied fracture mechanics principles to analyze the test data existing in literature. The cracking produced by shear was assumed to propagate with a dispersed zone of microcracks at the fracture front. To take the dispersed and progressive nature of cracking at the fracture front into account, some assumptions have been introduced: the total potential energy release caused by fracture in a given structure is a function of both the length of the fracture and the area of the cracked zone. Dimensional analysis of the energy release rate then showed that the nominal shear stress at failure should not be a constant but should vary as $\left(1+d / d_{a} \lambda_{0}\right)^{-0.5}$, in which $d$ is beam depth, $d_{a}$ is the maximum aggregate size, and $\lambda_{0}$ is empirical constant. He observed that the size effect on the ultimate strength was insignificant in small beams. However, in much large beams the shear strength considerably decreased with increasing size. It was also found that the size effect had little or no influence on diagonal cracking strength.

It is already known that size effect occurs in both short and long beams with normal-strength concrete. In recent years with the rapidly increasing use of highstrength concrete, this issue becomes more important. High-strength concrete is generally known to be more brittle than normal-strength concrete. This will result in strong size effect in high-strength concrete beams. However, the experimental information on this subject is very limited. A systematic experimental program with two series of beams with $a / d$ of 2 and 3.5 is reported in this paper attempts to provide more data on shear behavior of high-strength concrete beams affected by size. The result should be useful for evaluating design methods used for high-strength concrete beams. The influence of the web reinforcement is also considered here. The code and equations included for comparison purpose are the ACI 318-95 Building Code [8], Zsutty's equation [9], Bazant's method [7], and Strutand-Tie model [10]. 


\section{MATERIALS AND MethodS}

This paper presents an investigation on the size effect in high-strength reinforced concrete beams. Two series of beams with $a / d$ of 2 and 3.5 is reported in this paper. The effective depth of specimens ranged from 200 to $700 \mathrm{~mm}$. The web reinforcement percentage of specimens ranged from 0 to $0.57 \%$. The experimental investigation is very useful to provide a verification to confirm that the ultimate shear stress is size dependent and the web reinforcement percentage does not affect the size effect. The 18 test results are then compared with predictions from the ACI Code, Zsutty's equation, Bazant's method, and Strut-and-Tie model to show the accuracy of each method in predicting the trend on the influence of effective depth in highstrength reinforced concrete beams.

Specimen Details. Eighteen simply supported reinforced high-strength concrete beams were to be tested under two-point loading. It is already known that the thickness of the beams has no contribution to size effect [6], so all test beams were chosen to have the same width of $185 \mathrm{~mm}$. The test beams were divided into two series with different $a / d$ ratio of 2 and 3.5. In each series, three groups of beams were cast according to the different percentages of web reinforcement. In each group the effective depths of the specimens were varied from 200 to $700 \mathrm{~mm}$, whereas all other variables remained constant. The specimen dimensions and other parameters are given in Table 1 . The beams were geometrically scaled appropriately in all respects (see Fig. 1) except the maximum aggregate size which is maintained at $20 \mathrm{~mm}$. Previous investigation by Wal- raven [5] indicated that there was no significant influence of the maximum aggregate size on the size effect in shear behavior. All of the specimens were designed to fail in shear as far as possible.

Materials. The compressive strength of the concrete was designed to be about $100 \mathrm{MPa}$ for all the specimens. The slump of the mix was about $200 \mathrm{~mm}$. Two $150 \times 150 \times 150 \mathrm{~mm}$ concrete cubes and two $150 \times$ $300 \mathrm{~mm}$ concrete cylinders were cast and tested together with each specimen to obtain the compressive strength of concrete, $f_{c u}$ and $f^{\prime}{ }_{c}$. Since the beams were cast in different batches, regression analyses were carried out for concrete compressive strength in each batch. Different average concrete strength of each beam specimen was then obtained from the results of these regression curves according to the age of specimen at the time of testing. The results are given in Table 1.

To prevent flexural failure from taking place, a relatively high percentage of main steel ratio of 3.98 percent was employed for all two series of specimens. There are two types of reinforcement bars used in the beam specimens: deformed high tensile steel ( $\mathrm{T}$ bar) and plain round mild steel ( $\mathrm{R}$ bar). The average yield stresses of the steels used in the specimens are tabulated in Table 1. Note that T10 indicates a T bar of 10 $\mathrm{mm}$ diameter, etc. Details of the reinforcements within each group are shown in Fig. 1. The mean yield strength $f_{y s}$ of these main bars was $512 \mathrm{MPa}$.

TABLE 1

DETAILS OF 18 EXPERIMENTAL BEAMS.

\begin{tabular}{|c|c|c|c|c|c|c|c|c|c|c|c|c|c|c|}
\hline Groups & $\begin{array}{c}\text { Beam } \\
\text { Notations }\end{array}$ & \multicolumn{5}{|c|}{ Beam dimension } & \multicolumn{2}{|c|}{ Concrete strength } & \multicolumn{2}{|c|}{ Steel strength } & \multicolumn{2}{|c|}{$\begin{array}{l}\text { Main tension } \\
\text { reinforcement }\end{array}$} & \multicolumn{2}{|c|}{$\begin{array}{l}\text { Vertical web } \\
\text { reinforcement }\end{array}$} \\
\hline \multirow{3}{*}{1} & B-2-200 & 185 & 250 & 200 & 400 & 1300 & 89 & 1 & 512 & 0 & 1480 & 3.98 & - & - \\
\hline & B-2-400 & 185 & 475 & 400 & 800 & 2600 & 95 & 1 & 512 & 0 & 2960 & 3.98 & - & - \\
\hline & B-2-700 & 185 & 825 & 700 & 1400 & 4550 & 92 & 3 & 512 & 0 & 5180 & 3.98 & - & - \\
\hline 2 & $V-2-400$ & 185 & 475 & 400 & 800 & 2600 & 95 & 1 & 512 & 518 & 2960 & 3.98 & 157 & 250 \\
\hline \multirow{5}{*}{3} & V-2-700 & 185 & 825 & 700 & 1400 & 4550 & 98 & 3 & 512 & 518 & 5180 & 3.98 & 157 & 250 \\
\hline & VV-2-200 & 185 & 250 & 200 & 400 & 1300 & 75 & 4 & 512 & 518 & 1480 & 3.98 & 157 & 150 \\
\hline & VV-2-400 & 185 & 475 & 400 & 800 & 2600 & 95 & 1 & 512 & 518 & 2960 & 3.98 & 157 & 150 \\
\hline & VV-2-700 & 185 & 825 & 700 & 1400 & 4550 & 98 & 3 & 512 & 518 & 5180 & 3.98 & 157 & 150 \\
\hline & \multicolumn{14}{|c|}{ Series 2} \\
\hline \multirow{3}{*}{2} & $V-3.5-200$ & 185 & 250 & 200 & 700 & 1900 & 85 & 2 & 512 & 518 & 1480 & 3.98 & 57 & 91 \\
\hline & V-3.5-400 & 185 & 475 & 400 & 1400 & 3800 & 85 & 2 & 512 & 518 & 2960 & 3.98 & 157 & 250 \\
\hline & V-3.5-700 & 185 & 825 & 700 & 2450 & 6650 & 102 & 1 & 512 & 518 & 5180 & 3.98 & 157 & 250 \\
\hline \multirow{3}{*}{3} & VV-3.5-200 & 185 & 250 & 200 & 700 & 1900 & 85 & 2 & 512 & 518 & 1480 & 3.98 & 157 & 150 \\
\hline & VV-3.5-400 & 185 & 475 & 400 & 1400 & 3800 & 85 & 2 & 512 & 518 & 2960 & 3.98 & 157 & 150 \\
\hline & VV-3.5-700 & 185 & 825 & 700 & 2450 & 6650 & 104 & 1 & 512 & 518 & 5180 & 3.98 & 157 & 150 \\
\hline
\end{tabular}

Notations: B-2-200 = "B" means beams without web reinforcement; 2 means $a / d$ ratio of 2; 200 is effective depth,; "V" means beams with web reinforcement percentage of 0.34 , "VV" means beams with web reinforcement percentage of 0.57 , etc. $b$-- width of the beam, $h--$ overall depth of beam, $d$-- effective depth of beam, $a$-- shear span, $l$-- overall length of beam, $\rho$-- main tension steel ratio, $\rho_{v}$-- web reinforcement ratio. 

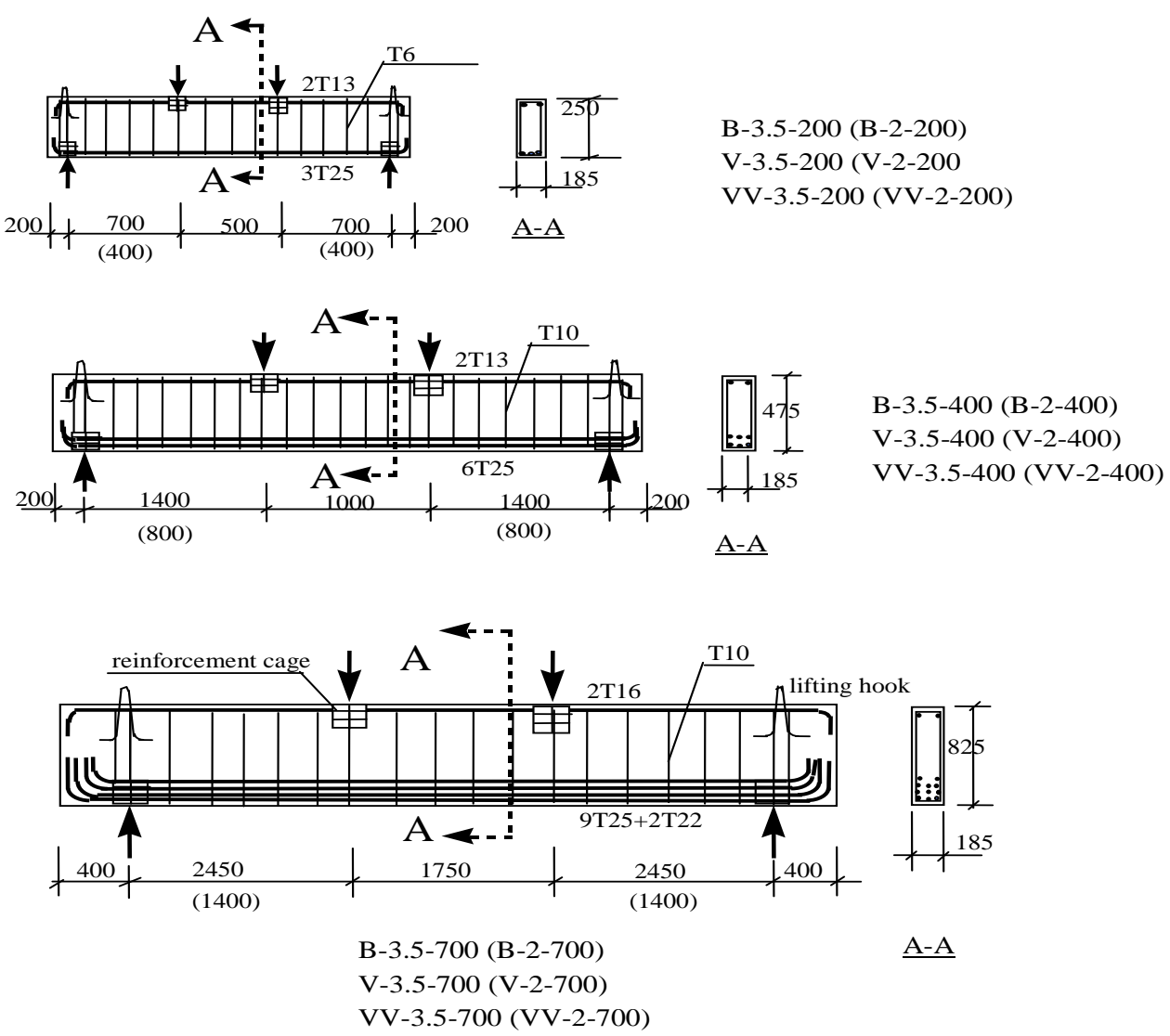

Notes: Three beams for each figure.

one beam without stirrups,

one beam with T10 stirrups at spacing $250 \mathrm{~mm}$, or T6 at spacing $90 \mathrm{~mm}$

one beam with T10 stirrups at spacing $150 \mathrm{~mm}$.

Same details were also used with $a / d$ of 2 beams

Fig. 1. Details of beam specimens

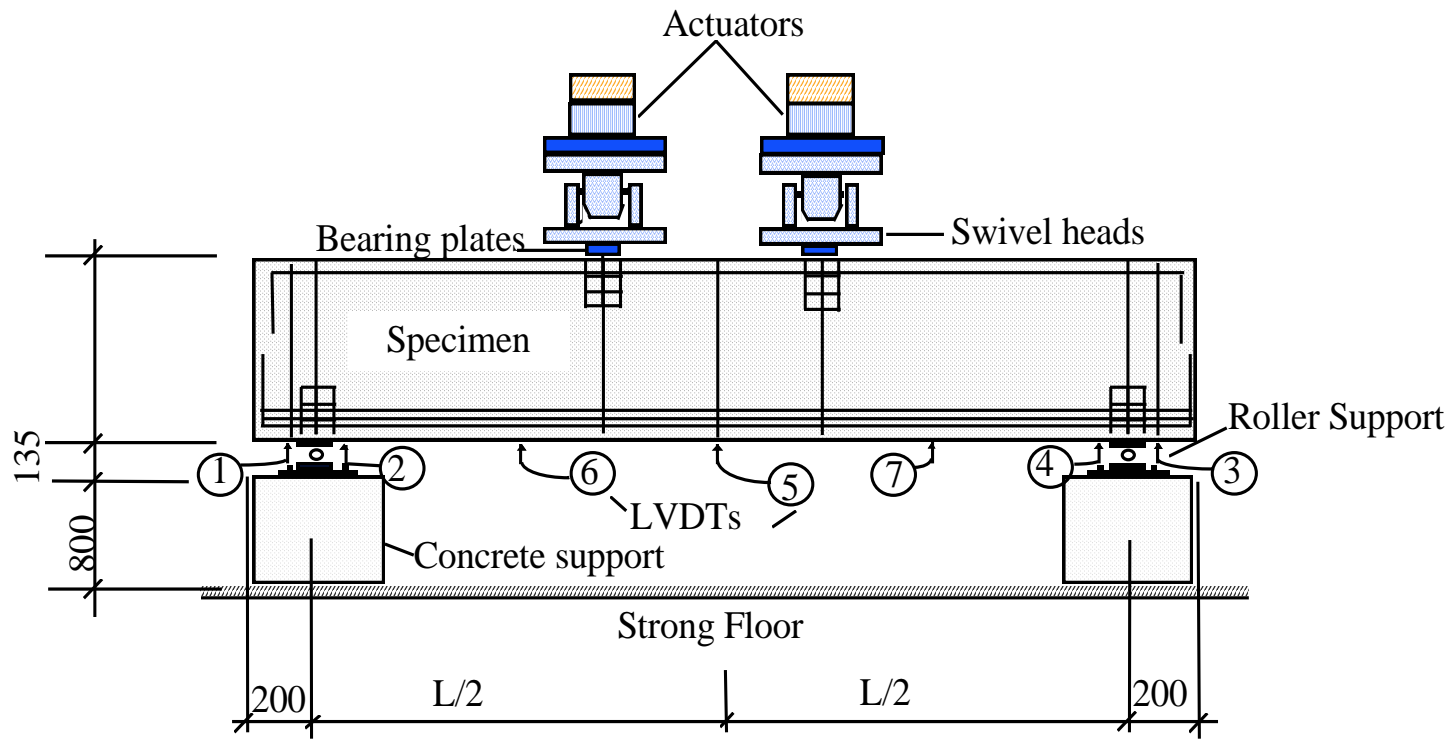

Fig. 2. Typical test set-up

Test Procedure. The typical set-up for specimens is shown in Fig. 2. The test specimens were loaded by two $1000 \mathrm{KN}$ actuators. Before testing, each specimen was white-washed on one surface and $150 \mathrm{~mm} \times 150$ $\mathrm{mm}$ grids were drawn in pencil to facilitate crack detection. Deflections of the beam specimens were measured using Linear Voltage Displacement Trans- ducers (LVDTs) located at the bottom central line of the beams at seven locations.

The flexural cracking stress, the initial inclined cracking shear stress and the ultimate shear stress were investigated. Furthermore, the influences of shear span to effective depth ratio $(a / d)$, web reinforcement percentage and effective depth on those three stresses were investigated. 


\section{RESULT AND DISCUSSIONS}

Deflections. The midspan deflections of all the test beams are shown in Fig. 3, plotted against shear stress $v_{u}=V_{u} /(b d)$. Compared to normal-strength concrete beams, these curves are relatively more linear indicating the more brittle nature of the failure of the highstrength concrete beams. Within each figure the influence of percentage of web reinforcement is also shown. The difference in inclination of these curves occurred mostly after the formation of inclined cracks indicating that providing web reinforcement in the shear spans would increase the stiffness of these beams after diagonal cracking occurred.

Flexural Cracking. The flexural and inclined cracking loads, ultimate loads, and the failure modes of the 18 beams are shown in Table 2 . The first crack to form in all the test beams was the flexural crack which formed close to the bottom of the beam in the mid-span region. The stress in which the first flexural crack formed varied from 5 to 25 percent of the ulti-
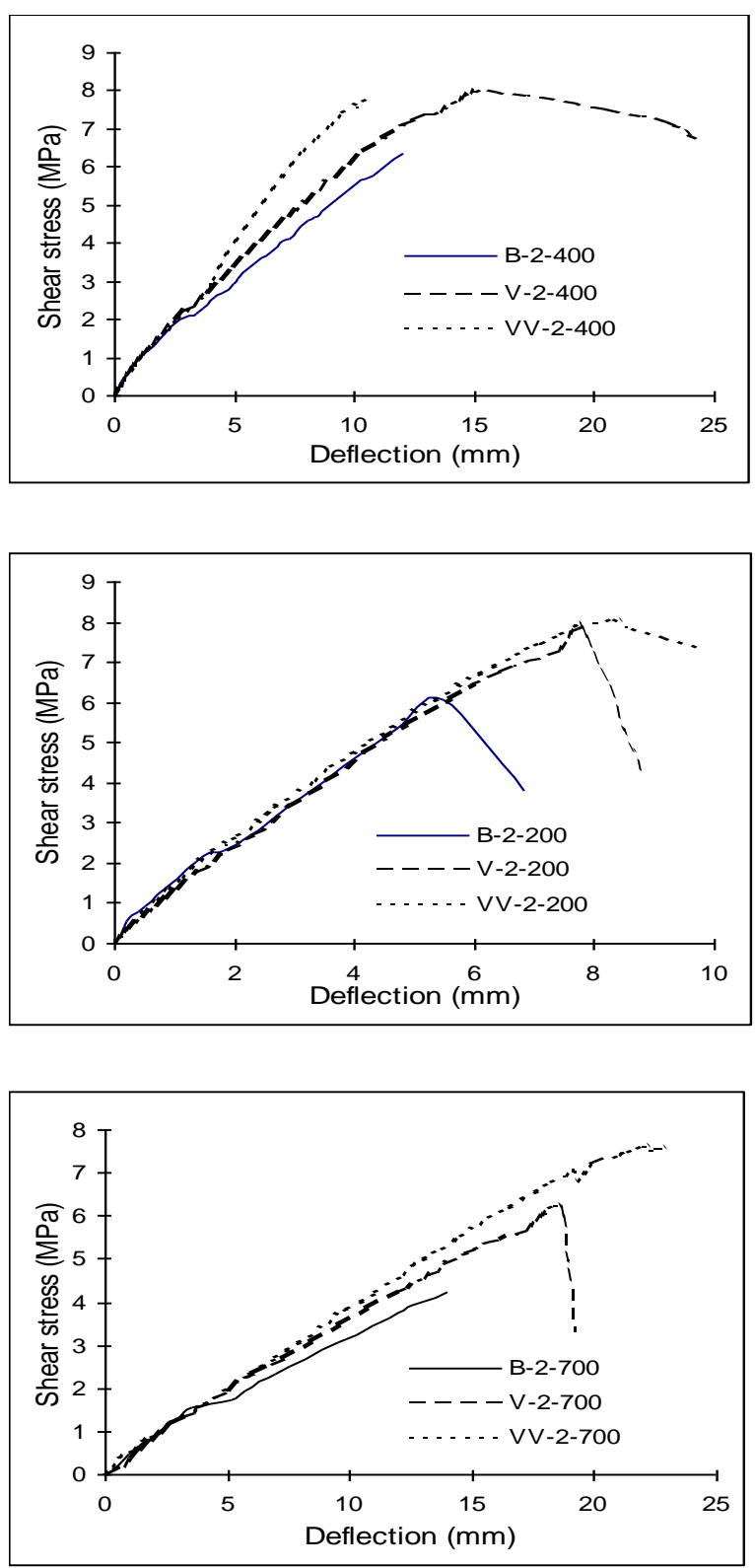

mate loads. Generally, the flexural crack development would slow down or even stop soon after the diagonal crack formed. It can be observed in Table 2 that web reinforcement has no significant delaying effect in the formation of the first flexural crack because the flexural crack appears just when the principal tensile stress in the concrete exceeds its tensile strength. It is worth noting that Fig. 4 shows no clear size effect on the flexural crack formation.

Inclined Cracking. Unlike that of the flexural cracks, the formation of the inclined cracks was rather sudden and with a thud, especially in beams without web reinforcement. The width of the inclined crack when it was first measured was around $0.1 \mathrm{~mm}$ and it increased rapidly with additional load. Generally the crack widths of beams with web reinforcement are around $2 \mathrm{~mm}$ at failure, while the crack widths of beams without web reinforcement are usually over 3 $\mathrm{mm}$ at failure.
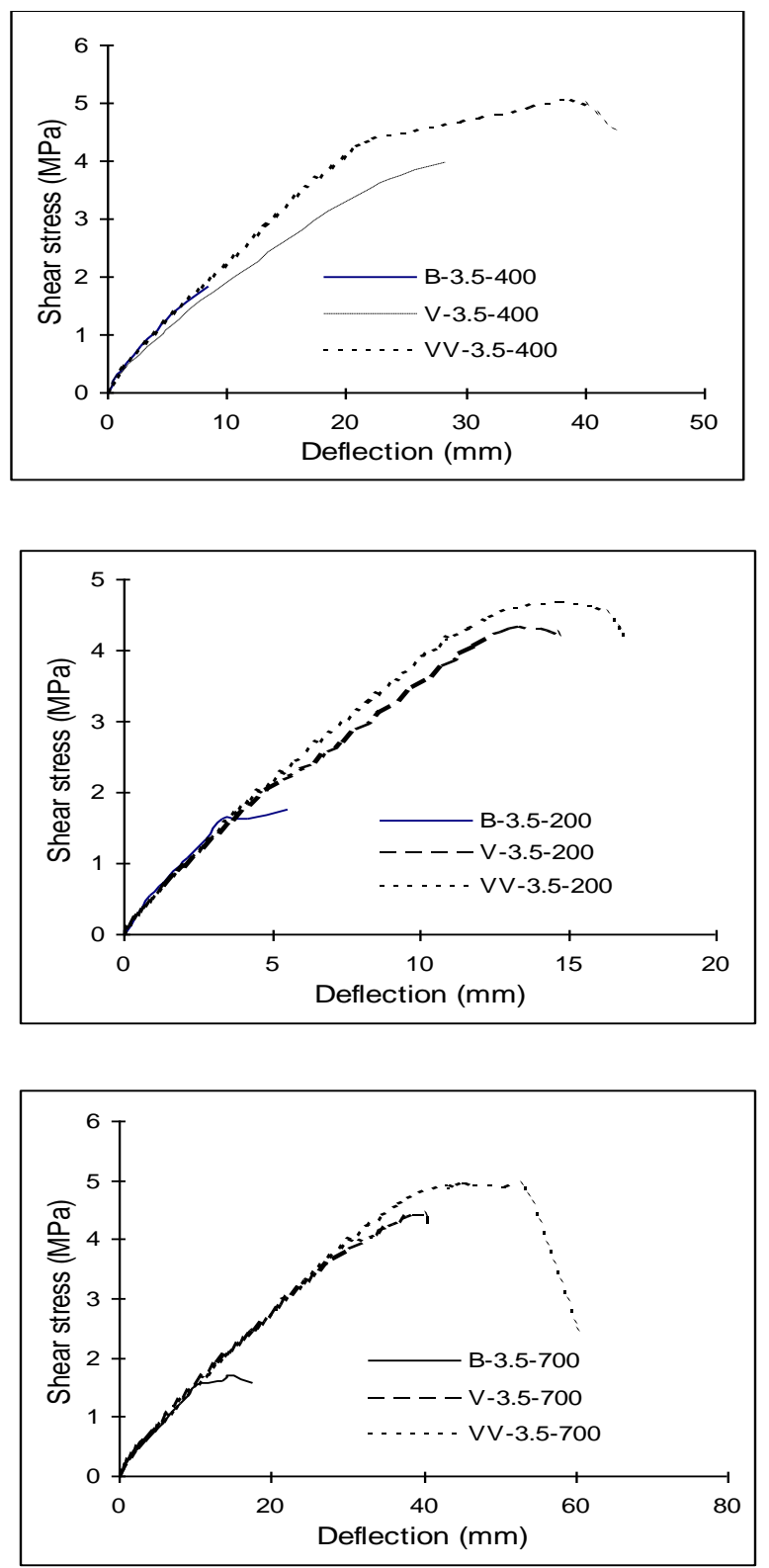

Fig. 3. Shear stress versus mid-span deflection with different web reinforcement 

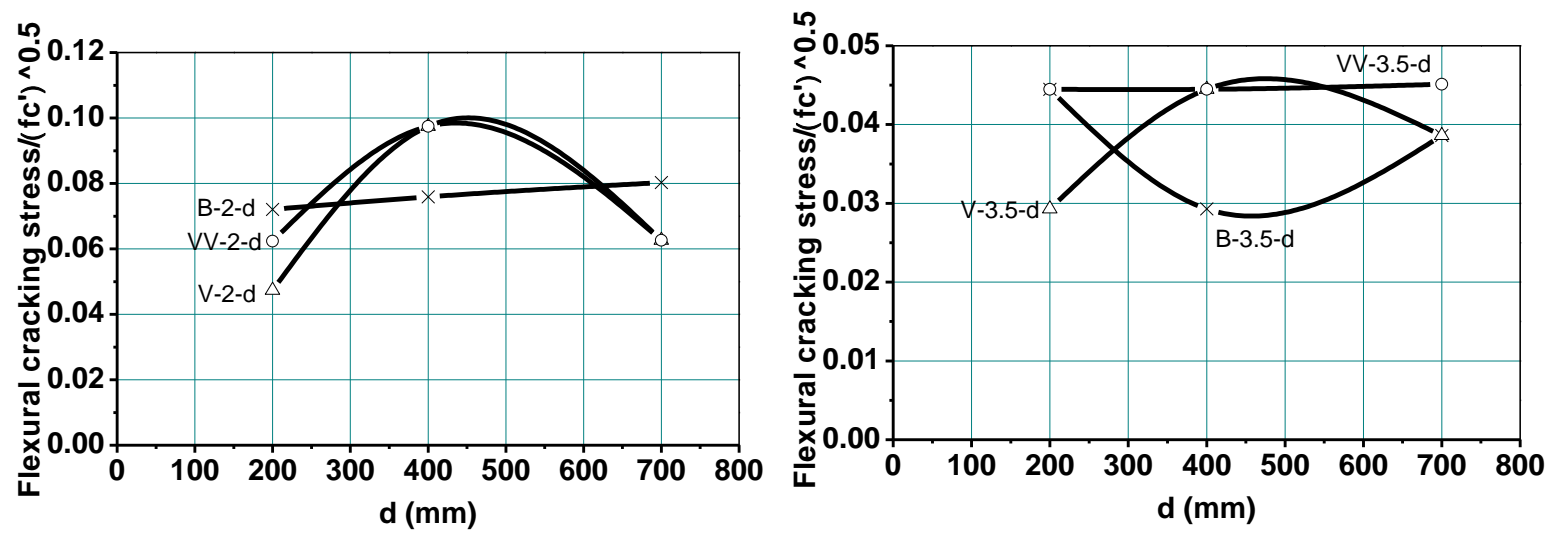

Fig. 4. Influence of effective depth on flexural cracking stress
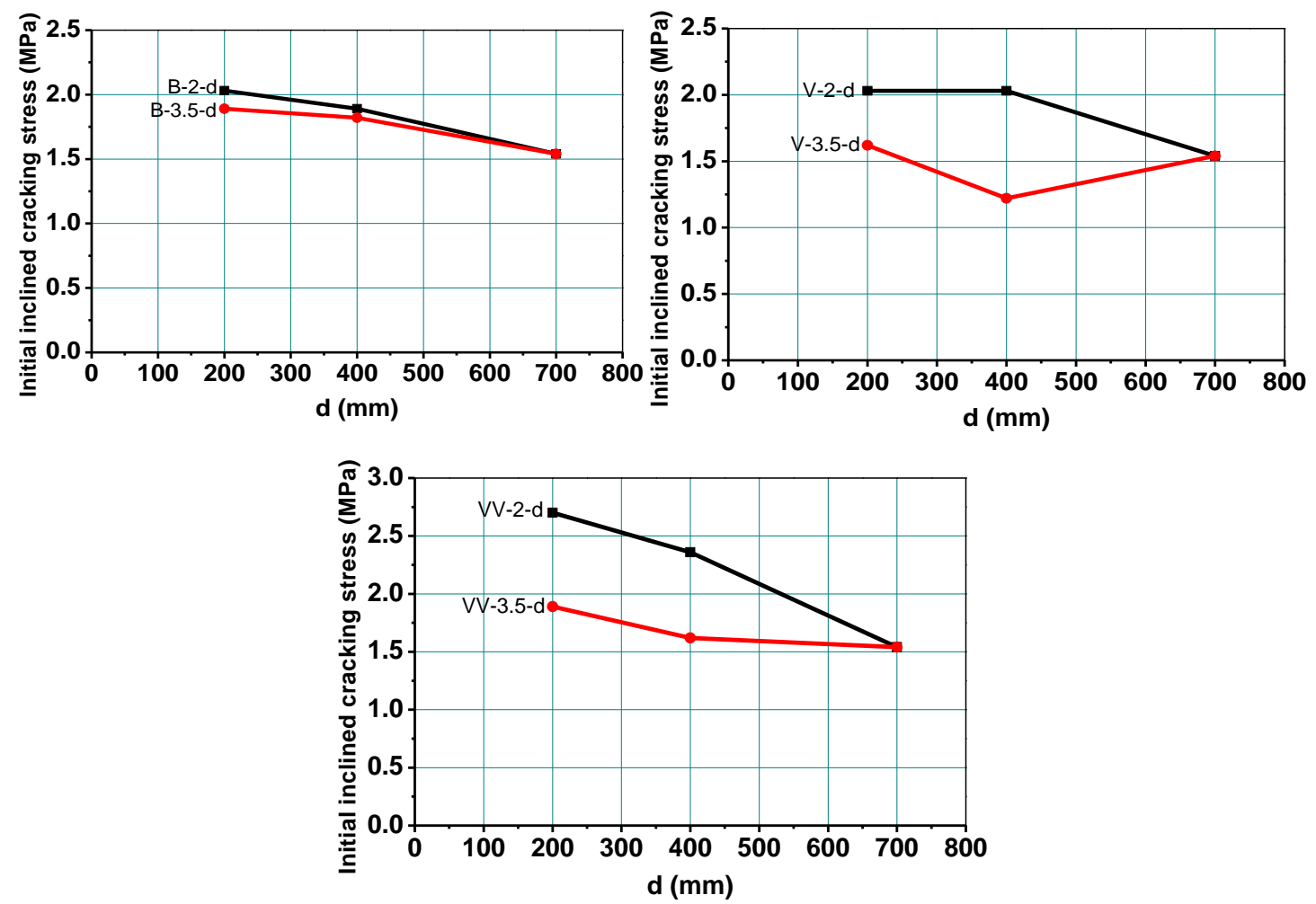

Fig. 5. Influence of the a/d ratio on the initial inclined cracking stress

The values of the inclined cracking stresses as shown in Table 2 are scattered. They were sensitive to the judgment of the observer during testing. The beams without web reinforcement having $a / d$ of 3.5 (B-3.5-200, and B-3.5-400, and B-3.5-700) failed when the first diagonal crack occurred. For beams without web reinforcement having $a / d$ of 2 (B-2-200, and B-2-400, and B-2-700), their diagonal cracking stresses ranged from 29 to 35 percent of the ultimate stresses. For the beams with web reinforcement, the diagonal cracking stresses were ranging from 20 to 40 percent of ultimate stresses.

Table 2 also shows that web reinforcement has little effect on the initial inclined cracking. This is expected since only after diagonal cracks occur does the web reinforcement begin to function and delay the further development of the diagonal cracks which lead to the final shear failure of the beams. Therefore, web reinforcement has significant beneficial effect on the ultimate load. Fig. 5 shows the influence of $a / d$ ratio on the initial inclined cracking stresses. Except for the beams with $700 \mathrm{~mm}$ effective depth, a/d ratio has some influence on the initial inclined cracking stress for the smaller beams. Such influence is slight and insignificant for the beams without web reinforcement, and might be pronounced for the beams with web reinforcement.

Fig. 6 shows the influence of the effective depth on the initial inclined cracking stress within these three series. Except for one group (V-3.5-200, V-3.5-400, $\mathrm{V}-3.5-700)$ the other five groups of beams show slight size effect on the initial diagonal crack. This is different from previous investigation by Bazant and Kim [6] which concluded that the size effect should be nonexistent for the true crack initiation. Because the initial diagonal crack stresses are sensitive to the judgment of the observer, we could not get the conclusion that whether or not there is size effect existed in the initial crack stresses. 

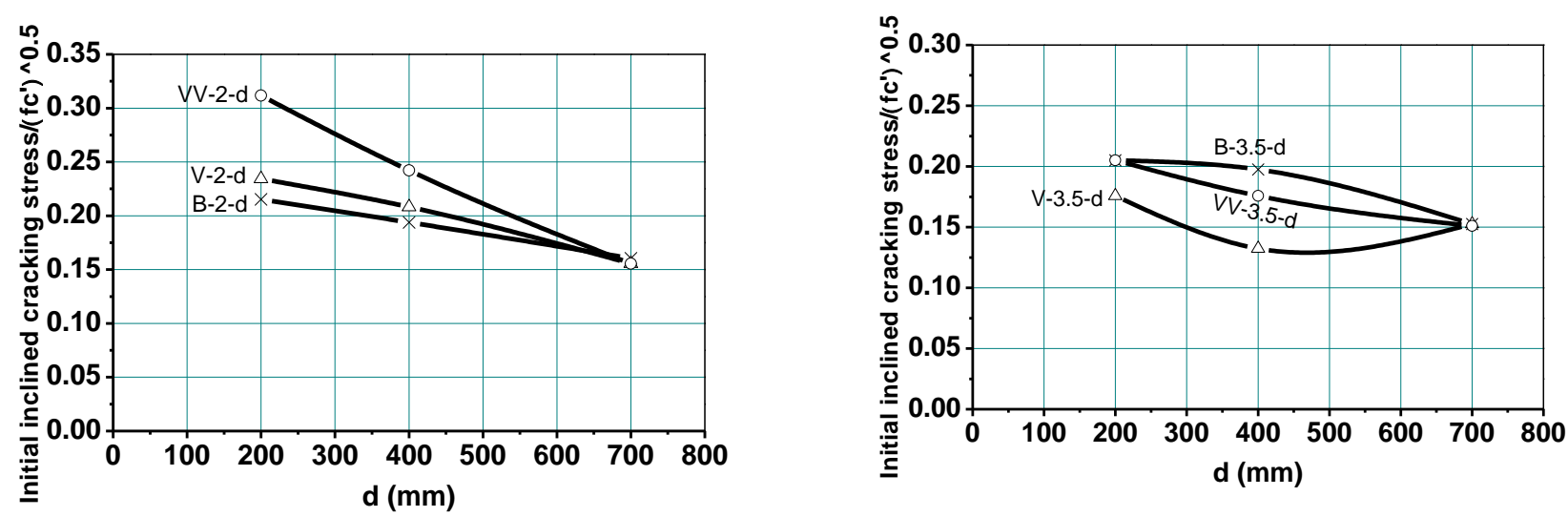

Fig. 6. Influence of effective depth on the initial inclined cracking stress

Crack Pattern and Failure Modes. Fig. 7 shows the crack distributions for all 18 beams together with the total loads at which each crack was first observed, as obtained by accurate mapping of each individual beam after failure. The failures of beams having web reinforcement were slower and were in a more ductile mode. The shear failure modes of beams vary with the shear span to depth ratio and the amount of longitudinal steel content (Ahmad, Khaloo, and Poveda [11]). In this experimental programme, we observed that the effective depth also have some influence on the failure modes. There are three types of shear failure in this project, namely: diagonal splitting and diagonal tension and shear compression. Diagonal splitting was the most common failure mode of the beams with $a / d$ ratio of 2. Beam specimens with $a / d$ ratio of 3.5 always failed by diagonal tension. Note that, beam VV-2-200, VV-2-400, VV-3.5-200, VV-3.5-400, and VV-3.5-700 failed in flexure by crushing of the compression zone. It is noted that beam VV-2-700 with heavier web reinforcement failed in shear compression, while the other two beams in the same group (VV-2-200, VV-2400) failure in flexure. This is due to the pronounce size effect for large size short beam. The shear capacity in these beams is less than the small size beams, while the flexure capacity remains the same. Therefore large size beams with small $a / d$ ratio tend to fail in shear than the similar beams with small sizes.

Influence of a/d Ratio. The ultimate shear stresses of the beams are summarized in Table 2. As expected, the beams with a/d ratio of 2 showed substantially higher shear strength than those with $a / d$ ratio of 3.5. This can be attributed to arch action in the beam. Many researchers have shown that for small $a / d$ ratio, part of the load is transmitted directly by diagonal compression to the supports. This is not a shear transfer mechanism, because it does not transmit a tangential force to a nearby parallel plane, but permits the transfer of a vertical concentrated force to a reaction and thereby reduces the demand on other types of load transfer mechanisms and increases the failure load. Fig. 8 shows that for beams without web reinforcement, ultimate shear stress of beams with $a / d$ of 2 is more than 3 times that of the beams with $a / d$ of 3.5 .
For the beams with web reinforcement, the difference is smaller.

It is generally known that increasing $a / d$ decreases the shear strength in shallow beams although there is no arch action in these beams. For the same applied load, larger $a / d$ means larger bending moment in the shear span. Therefore, the depth of penetration of the flexural cracks increases, and also the inclined crack width increases. The decrease of the shear strength carried by aggregate interlock and the uncracked compression zone will result. Previous researcher Elzanaty et al. [12] found that for higher web reinforcement ratio, increasing $a / d$ ratio of the shallow beams, the reduction is slight. For lower web reinforcement ratio, such reduction is significant. This is due to the yielding of the longitudinal reinforcement at the failure, which limited the shear transfer at the crack location including the aggregate interlock and the dowel action of the longitudinal reinforcement.

Influence of Web reinforcement. Web reinforcement can greatly enhance the shear capacity especially in beams having larger a/d ratio. Providing web reinforcement in concrete beams ensures the formation of the internal truss system.

The general equation of beam shear strength is: $V_{n}=V_{c}+\rho_{v} f_{y}$, where $V_{c}$ and $\rho_{v} f_{y}$ are shear strength contributed by the concrete and web steel contributions, respectively, and $\rho_{v}$ is the web reinforcement ratio. Here we can observe that $V_{c}$ is not a constant which equal to the shear strength of the beams without web reinforcement. This is due to the fact that web reinforcements not only carry shear themselves but also enhance the strength of the other shear transfer mechanisms. The web reinforcements provide support for the longitudinal reinforcement and prevent the main bar from splitting from the surrounding concrete, thus greatly increase the strength of dowel action. Meanwhile the web reinforcements help to contain the crack, limit its propagation and keep its width small. These effects increase both the shear strength carried by aggregate interlock and the shear strength of the uncracked compression zone. Web reinforcements also increase the strength of the compression strut of the internal truss system by providing 
confinement. Although they do not affect the initial inclined cracking stress, they enhance the concrete contribution at the ultimate shear strength by increasing the capacity of the different shear transfer mechanisms.

Influence of Effective Depth d. Fig. 9 shows the influence of the effective depth on the ultimate stress of testing beams. As indicated, the failure mode of Beam VV-2-200, VV-2-400, VV-3.5-200, VV-3.5400, VV-3.5-700 are flexure failure. The figure shows more or less size effect on the ultimate shear strength, especially for those short beams. Because the shear capacity in short beams consists of beam action and arch action (strut and tie mechanism), and the latter component is strongly affected by the size effect (Walraven and Lehwalter [3]).

It is also worth noting that the same trend size effect occurred in both beams with and without web reinforcement. In other words, there is no size effect in the shear strength contributed by the web reinforcement.

However, for beams from $d$ of $200 \mathrm{~mm}$ to $d$ of 400 $\mathrm{mm}$, this effect is very small and insignificant. As for the beams with a large size $(d=700 \mathrm{~mm})$, this size effect begins to be pronounce especially for the short beams. This phenomenon is approved by the previous investigation conducted by Bazant and Sun [7]. For very small size beams, the strength criterion is dominant and there is no significant size effect, while for large size beams, the size effect is according to the linear elastic fracture mechanics described by the inclined straight line.
Comparison of Test Result with Share Design Equations. Four design methods are compared to assess their safety and accuracy for shear strength predictions of 18 high-strength concrete beams. The four predictions are those according to: ACI Code, Zsutty's method, Bazant's method, and Strut-and-Tie model.

ACI Code (ACI 318-95 [8]). ACI Code is based on the traditional method of $45^{\circ}$ truss model and the equations used are:

$V_{u}=V_{c}+V_{s}$

$a / d>2.5: V_{c}=\left(0.16 \sqrt{f_{c}^{\prime}}+17.2 \rho \frac{V_{u} d}{M_{u}}\right) b d \leq 0.3 \sqrt{f_{c}^{\prime}} b d$

$a / d \leq 2.5{ }^{\circ} V_{c}=\left(3.5-2.5 \frac{M_{u}}{V_{u} d}\right)\left(0.16 \sqrt{f_{c}^{\prime}}+17.2 \rho \frac{V_{u} d}{M_{u}}\right) b d \leq 0.5 \sqrt{f_{c}^{\prime}} b d$

$V_{s}=\frac{A_{v}}{s_{v}} f_{v y} d$

where $f_{c}^{\prime}$ is the cylinder compressive strength of concrete $(\mathrm{MPa}), b$ is the beam width, $\mathrm{mm} ; d$ is the effective depth of beam, mm; $\rho$ is the main longitudinal reinforcement ratio $A_{s} /(b d) ; M_{u}$ is the factored moment at the critical section, N-mm; $V_{u}$ is the factored shear force at the critical section, $\mathrm{N} ; A_{v}$ is the area of web reinforcements at a cross section, $\mathrm{mm}^{2}$, $s_{v}$ is the spacing between web reinforcements, mm; and $f_{v y}$ is the yield strength of web reinforcement, MPa.

TABLE 2

CRACKING LOADS, ULTIMATE LOADS AND FAILURE MODES OF 18 CONCRETE BEAMS

\begin{tabular}{cccccccc}
\hline $\begin{array}{c}\text { No. } \\
\text { of } \\
\text { Beams }\end{array}$ & $\begin{array}{c}\text { Beam } \\
\text { Notations }\end{array}$ & $\begin{array}{c}\text { Cracking Stress (MPa) } \\
\text { Flexural }\end{array}$ & $\begin{array}{c}\text { Diagonal } \\
\text { vf }\end{array}$ & $\begin{array}{c}\text { Ultimate } \\
\text { Stress } \\
\text { vd }\end{array}$ & $\begin{array}{c}\text { Modes } \\
\text { Vu }\end{array}$ & $\begin{array}{c}\text { Failure } \\
\text { of }\end{array}$ & Ratios of Loads \\
vfu & vd /vu \\
\hline 1 & B-2-200 & 0.68 & 2.03 & 6.28 & DS & 0.10 & 0.32 \\
2 & V-2-200 & 0.41 & 2.03 & 7.57 & DS & 0.05 & 0.27 \\
3 & VV-2-200 & 0.54 & 2.7 & 8.23 & FC & 0.07 & 0.33 \\
4 & B-3.5-200 & 0.41 & 1.89 & 1.89 & DT & 0.22 & 1.00 \\
5 & V-3.5-200 & 0.27 & 1.62 & 4.32 & DT & 0.06 & 0.38 \\
6 & VV-3.5-200 & 0.41 & 1.89 & 4.69 & FC & 0.09 & 0.40 \\
7 & B-2-400 & 0.74 & 1.89 & 6.49 & DS & 0.11 & 0.29 \\
8 & V-2-400 & 0.95 & 2.03 & 8.11 & DS & 0.12 & 0.25 \\
9 & VV-2-400 & 0.95 & 2.36 & 8.23 & FC & 0.12 & 0.29 \\
10 & B-3.5-400 & 0.27 & 1.82 & 1.82 & DT & 0.15 & 1.00 \\
11 & V-3.5-400 & 0.41 & 1.22 & 5.03 & DT & 0.08 & 0.24 \\
12 & VV-3.5-400 & 0.41 & 1.62 & 5.07 & FC & 0.08 & 0.32 \\
13 & B-2-700 & 0.77 & 1.54 & 4.44 & DS & 0.17 & 0.35 \\
14 & V-2-700 & 0.62 & 1.54 & 6.22 & DS & 0.10 & 0.25 \\
15 & VV-2-700 & 0.62 & 1.54 & 7.61 & SC & 0.08 & 0.20 \\
16 & B-3.5-700 & 0.39 & 1.54 & 1.54 & DT & 0.25 & 1.00 \\
17 & V-3.5-700 & 0.39 & 1.54 & 4.4 & DT & 0.09 & 0.35 \\
18 & VV-3.5-700 & 0.46 & 1.54 & 4.79 & FC & 0.10 & 0.32 \\
\hline
\end{tabular}




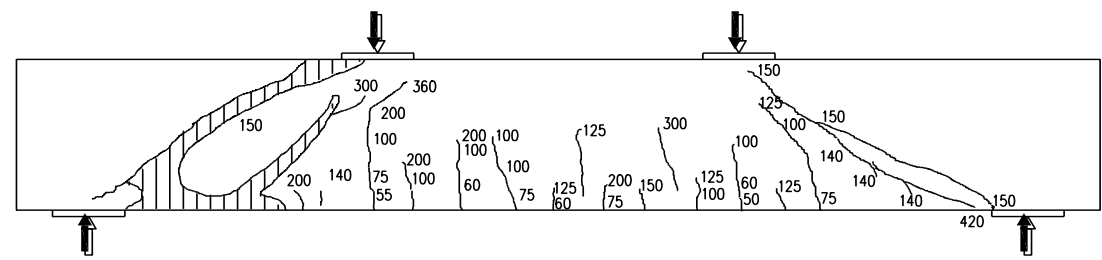

$\underline{B-2-400}$

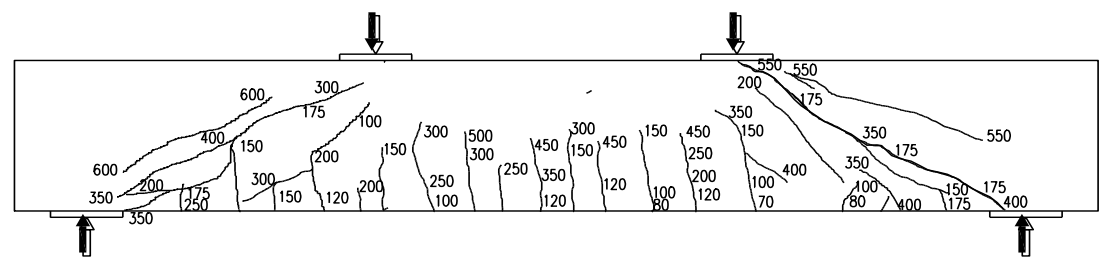

$\underline{\mathrm{V}-2-400}$

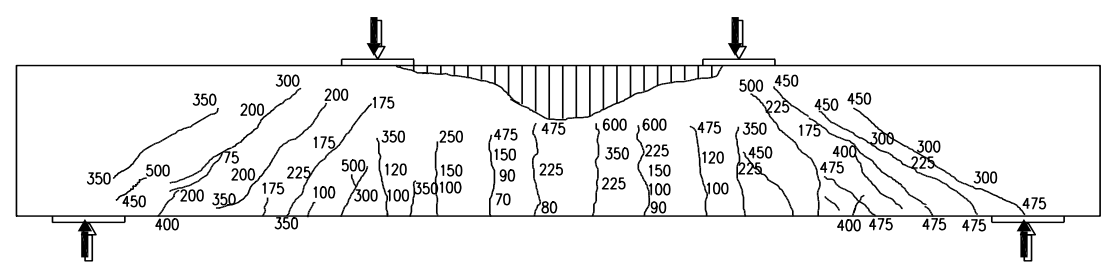

$\underline{\mathrm{VV}-2-400}$
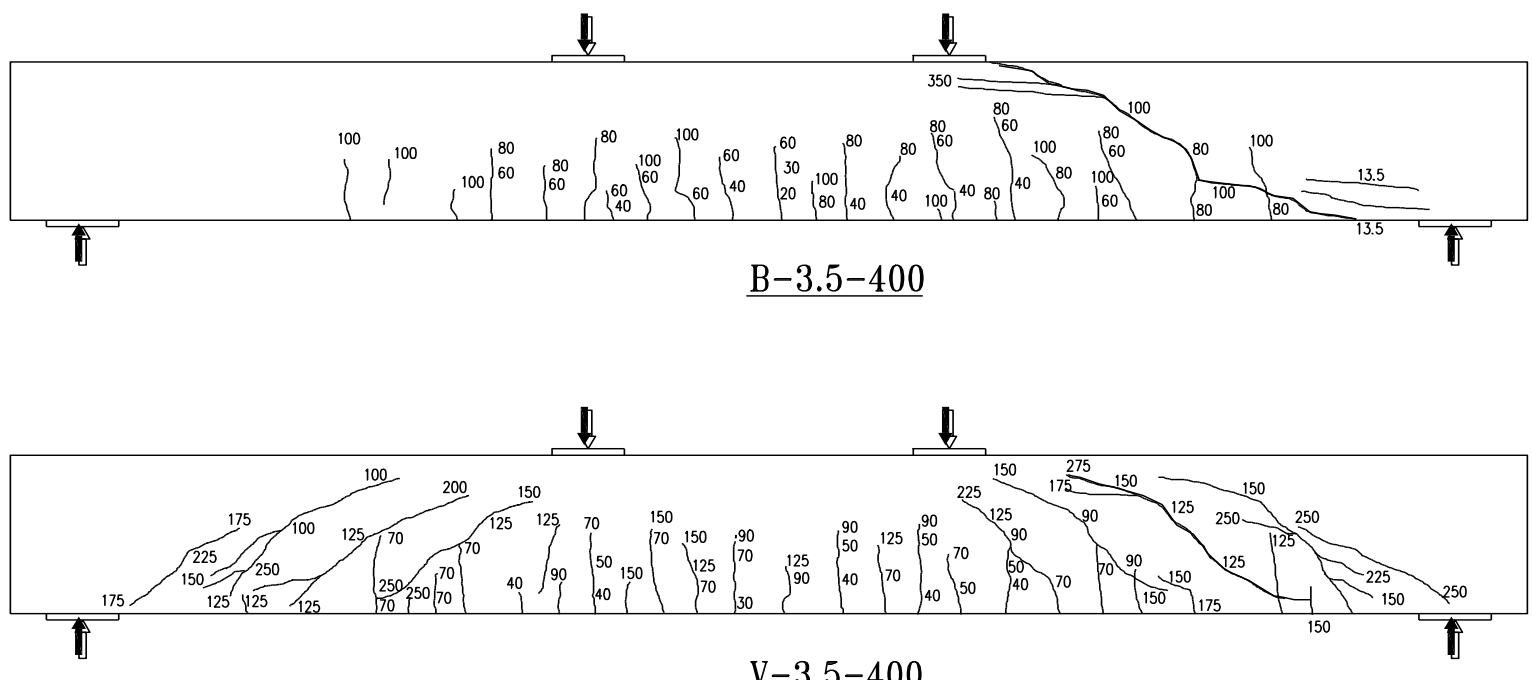

$\underline{\mathrm{V}-3.5-400}$

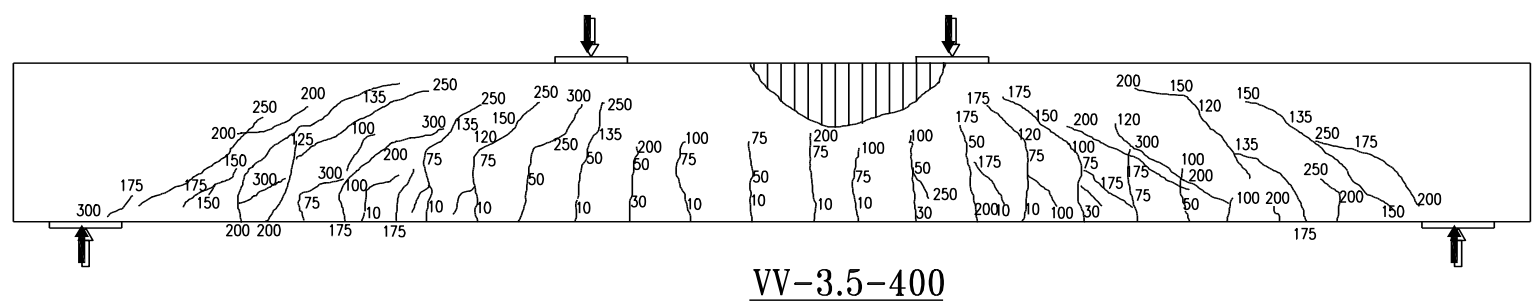

Fig. 7. Crack patterns at failure 


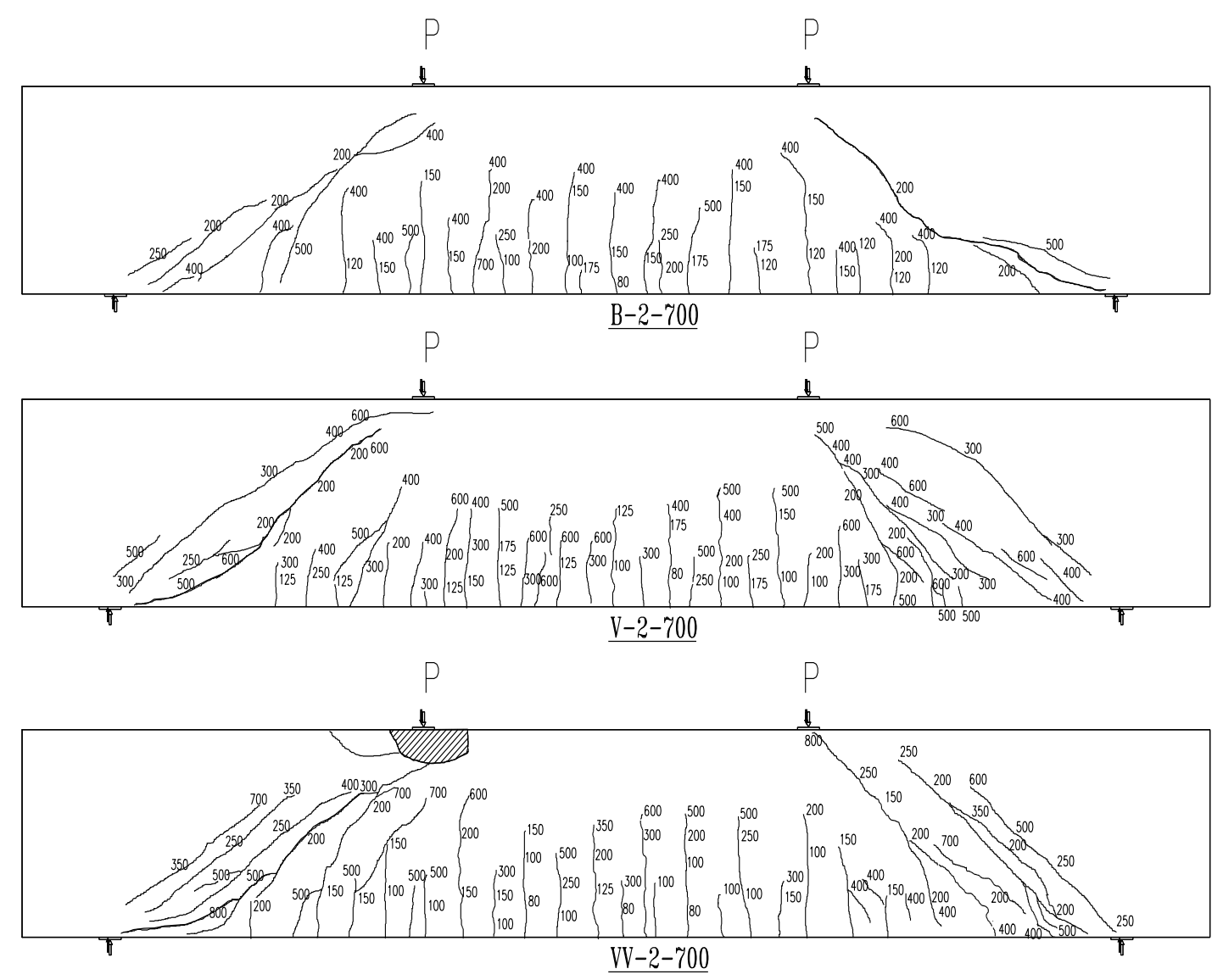

Fig. 7. Crack patterns at failure (Continued)

Zsutty's Equations [9]. Zsutty's formula is purely empirical, based on statistical analysis of the existing test data. The equations used are:

$a / d>2.5: V_{u}=2.3\left(f_{c}^{\prime} \rho \frac{d}{a}\right)^{0.333} b d+\frac{A_{v}}{s_{v}} f_{v y} d$

$a / d \leq 2.5: V_{u}=2.3\left(f_{c}^{\prime} \rho \frac{d}{a}\right)^{0.333}\left(\frac{2.5}{a / d}\right) b d+\frac{A_{v}}{s_{v}} f_{v y} d$

where $f_{c}^{\prime}$ is the cylinder compressive strength of concrete (MPa), $b$ is the beam width, $\mathrm{mm}$; $d$ is the effective depth of beam, $\mathrm{mm}$; $a$ is the shear span of beam, $\mathrm{mm} ; \rho$ is the main longitudinal reinforcement ratio $A_{s} /(b d) ; A_{v}$ is the area of web reinforcements at a cross section, $\mathrm{mm}^{2}, s_{v}$ is the spacing between web reinforcements, mm; and $f_{v y}$ is the yield strength of web reinforcement, MPa.

Bazant's Method [7]. Bazant's method is a fracture mechanics based formula which superimposes the shear forces transmitted by composite beam action and the arch action. The equations used are:

$V_{c}=\frac{10 \sqrt[3]{\rho}}{\sqrt{1+d / 25 d_{a}}}\left(0.083 \sqrt{f_{c}^{\prime}}+20.7 \sqrt{\rho /(a / d)^{5}}\right) b d$

$V_{s}=\frac{A_{v}}{s_{v}} f_{v y} d$

where $f_{c}^{\prime}$ is the cylinder compressive strength of concrete $(\mathrm{MPa}), b$ is the beam width, $\mathrm{mm} ; d$ is the effective depth of beam, $\mathrm{mm}$; $a$ is the shear span of beam, $\mathrm{mm} ; d_{a}$ is the maximum aggregate size, $\mathrm{mm}$; $\rho$ is the main longitudinal reinforcement ratio $A_{s} /(b d) ; A_{v}$ is the area of web reinforcements at a cross section, $\mathrm{mm}^{2}, S_{v}$ is the spacing between web reinforcements, $\mathrm{mm}$; and $f_{v y}$ is the yield strength of web reinforcement, MPa.

Strut-and-Tie Model [10]. A number of strut-andtie models $[10,13,14]$ have been proposed for design of reinforced concrete deep beams. A set of equations to estimate the shear strength was developed by Matamoros [10] based on simple strut-and-tie model. The principal mechanisms of shear resistance in deep beams with vertical web reinforcement can be recognized as two parts: an arch mechanism and a truss mechanism. The arch mechanism is represented by a direct strut between the load point and the support, as shown in Fig. 10(a). The inclined concrete strut was assumed to have a uniform width $W_{s t}$ defined by the geometry of the node at the support (Fig. 10(c)): $W_{s t}=l_{b} \sin \theta+W \cos \theta$

where $l_{b}$ is the width of bearing plate, $\mathrm{W}$ is twice the distance between the centroid of the main reinforcement and the bottom of the beam, and $\theta$ is the angle between the inclined strut and the main reinforcement that was approximated as $\theta \approx \arctan \left(\frac{d}{a}\right)$. 
The contribution of vertical web reinforcements to the total shear strength is carried by a truss in which the vertical tie (Fig. 10(b)) represents the vertical reinforcement. An effective width for the tie was defined to quantify the contribution of distributed reinforcement to the total shear strength. In typical deep beam

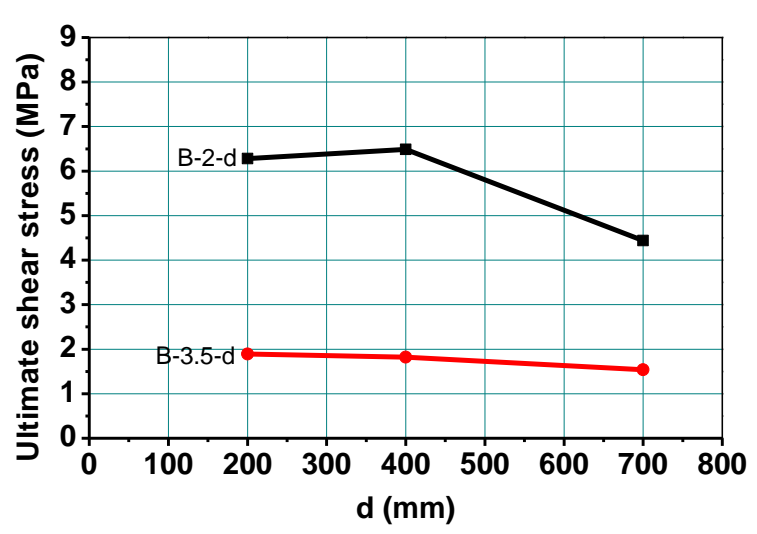

after cracking, strains near the support and the load are small. Furthermore, the tie located at the center of the shear span as shown in Fig. 10(b). So the effective width for the vertical tie was defined as $a / 3$, as shown in Fig. 10(d).

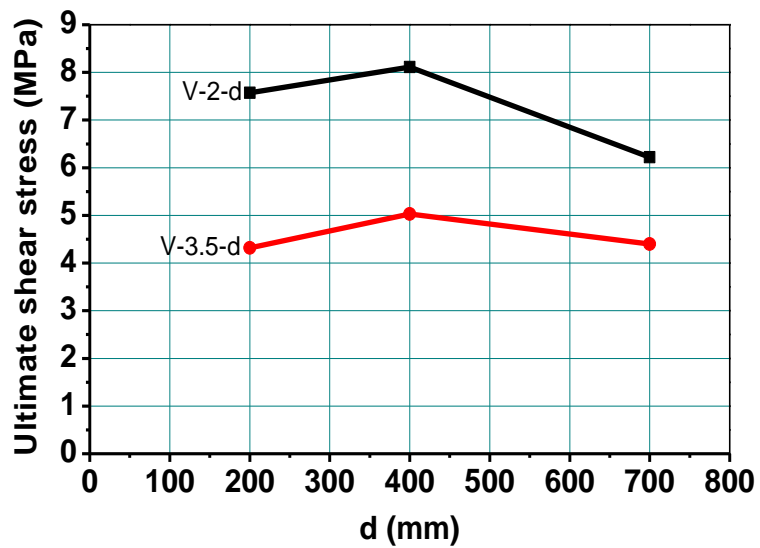

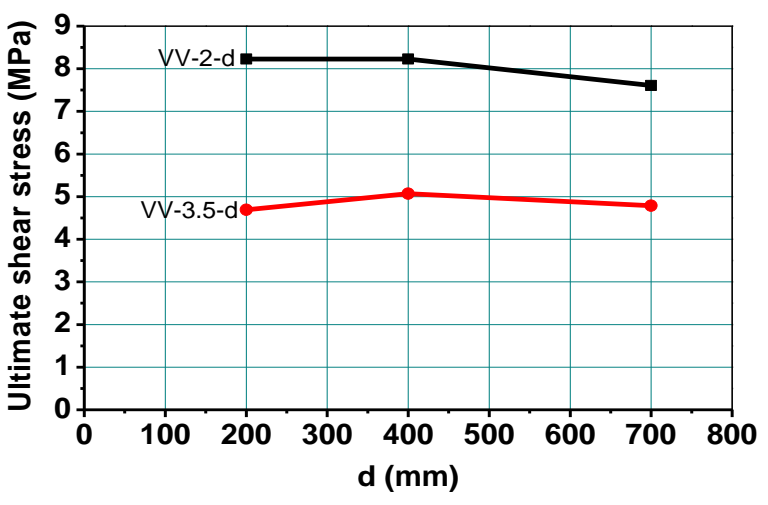

Fig. 8. Influence of the a/d ratio on the ultimate shear stress

The total shear strength of the deep beam with vertical web reinforcement is calculated as the sum of the components attributed to each of the two mechanisms.

$V=C_{c} S_{s t r u t}+C_{w v} S_{t v}=C_{c} f_{c}^{\prime} b W_{s t}+C_{w v} \rho_{w v} b \frac{a}{3} f_{v y}$

where $C_{c} S_{\text {strut }}$ is the contribution of inclined concrete strut, $C_{w v} S_{t v}$ is the contribution of vertical web reinforcement, $\rho_{w v}$ is the vertical reinforcement ratio, and $f_{v y}$ is the yield strength of the vertical reinforcement. The value of coefficient $C_{c}$ and $C_{w v}$ were obtained from experimental data by Matamoros [10].

$C_{c}=\frac{0.3}{a / d} \leq 0.85 \sin \theta, C_{w v}=1$

Fig. 11 presents the measured test results and four predicted values of shear capacities expressed in terms of shear stress. Table 3 shows the ratios of the predictions to the experimental values of the four different methods. In Table 3, beams VV-2-200, VV2-400, VV-3.5-200, VV-3.5-400, and VV-3.5-700 were not included, because they failed in flexure. Strut-and-Tie model is applicable for deep beams only, so the results of slender beams predicted by Strut-andTie model are not included in Table 3 and Fig. 11.

Beams without web reinforcement with $a / d=3.5$, shallow beams. Fig. 11(a) shows that ACI Code is safe for small beams but it may not be as safe for large beams. Zsutty's equation overestimates the strength of beams without web reinforcement, especially for the large size beam. Bazant's method predicts well the trend of size effect although it overestimates the shear strength of the beams.

Beams without web reinforcement with $a / d=2$, short beams (Fig. 11(b)). ACI Code states that the nominal concrete shear strength defined in the equation is based on the shear causing inclined crack. Unlike the shallow beams, which usually fail soon after the formation the inclined crack at the shear span, the short beams can still carried more load due to the arch action. The ultimate loads of the short beams are usually much higher than their inclined cracking load. Therefore, ACI Code gives rather conservative predictions for these short beams, but it still can be seen that this conservative trend decreases with the increase of the beam sizes. Both ACI Code and Zsutty's equation are safe for small beams and tend to be unsafe for the large beams. Bazant's method predicts the trend of influence of the effective depth is not as well as in shallow beams. It also underestimates the ultimate strength. Strut-and-Tie model predicts well the trend of influence of effective depth, but it overestimates the shear capacities of HSC deep beams.

Beams with web reinforcement with $a / d=3.5$, shallow beams. Bazant's method gives a relatively good prediction for such beams. ACI Code gives safe 
predictions, but it can be foreseen that its prediction may be unsafe for large size beams because its safe trend of prediction decreases with the increase of the beam sizes. Similar to ACI Code, Zsutty’s equation underestimates the shear strength for a small beam and tends to be unsafe for predicting the large beam.

TABLE 3

PREDICTION OF VARIOUS METHODS

\begin{tabular}{cccccc}
\hline \multirow{2}{*}{ Beam Notation } & \multicolumn{5}{c}{ Experimental result /Predicted shear strength } \\
\cline { 2 - 5 } & ACI & Zsutty & Bazant & Teng & Strut-and-Tie \\
\hline B-2-200 & 2.27 & 1.82 & 1.45 & 1.83 & 0.60 \\
B-2-400 & 2.27 & 1.82 & 1.67 & 2.28 & 0.90 \\
B-2-700 & 1.59 & 1.27 & 1.32 & 1.86 & 0.77 \\
B-3.5-200 & 1.75 & 1.49 & 1.28 & 0.70 & - \\
B-3.5-400 & 1.75 & 1.51 & 1.43 & 0.83 & - \\
B-3.5-700 & 1.33 & 1.16 & 1.20 & 0.78 & - \\
V-2-200 & 1.14 & 0.83 & 0.69 & 1.51 & 0.76 \\
V-2-400 & 1.09 & 0.80 & 0.76 & 1.76 & 0.97 \\
V-2-700 & 0.85 & 0.64 & 0.68 & 1.48 & - \\
V-3.5-200 & 1.27 & 1.07 & 0.96 & 0.97 & - \\
V-3.5-400 & 1.47 & 1.25 & 1.20 & 1.27 & - \\
V-3.5-700 & 1.23 & 1.05 & 1.10 & 1.18 & 0.94 \\
VV-2-700 & 1.56 & 1.30 & 1.19 & 1.41 & 0.83 \\
Mean value & 1.51 & 1.23 & 1.15 & 1.37 & 0.13 \\
Standard & 0.43 & 0.36 & 0.30 & 0.48 & 0.16 \\
Deviation & 0.28 & 0.29 & 0.26 & 0.35 & \\
COV & & & & \\
\hline
\end{tabular}
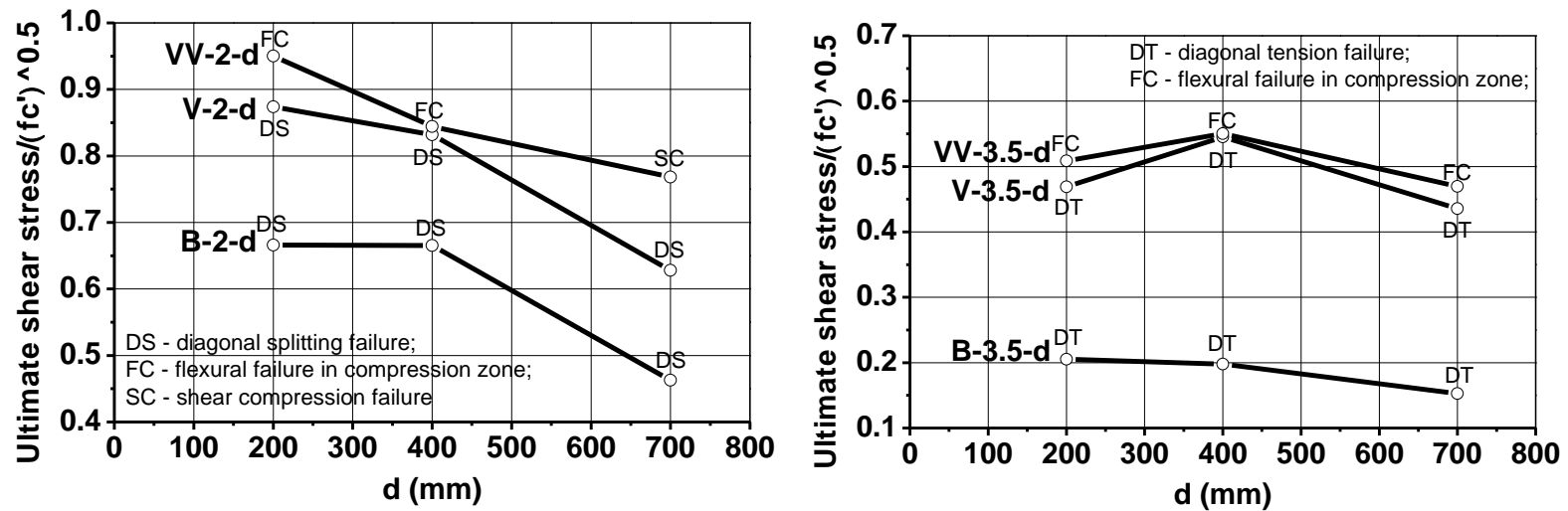

Fig. 9. Ultimate shear stress versus effective depth

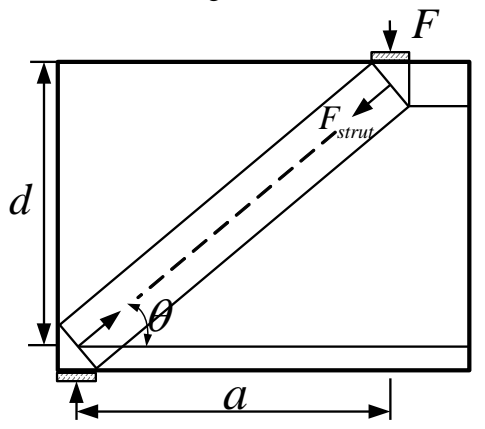

(a)

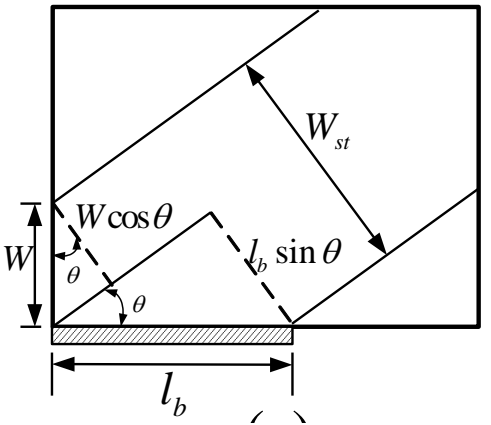

(c)

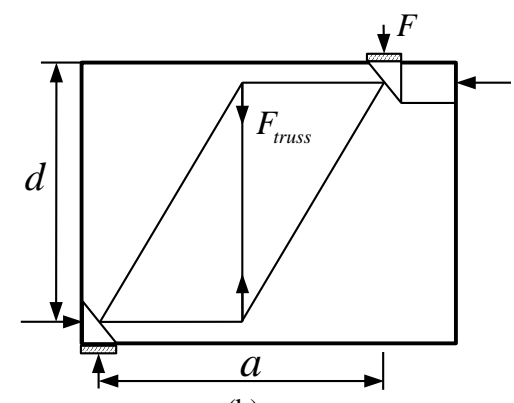

(b)

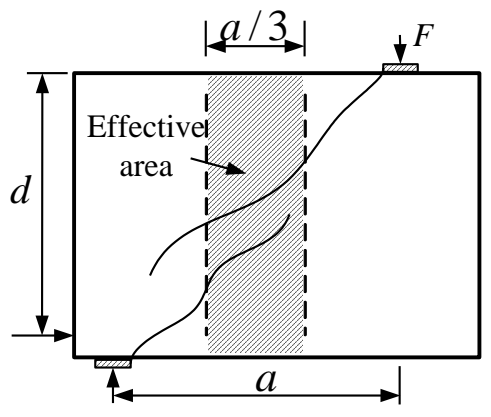

(d)

Fig. 10 Strut-and-Tie model 


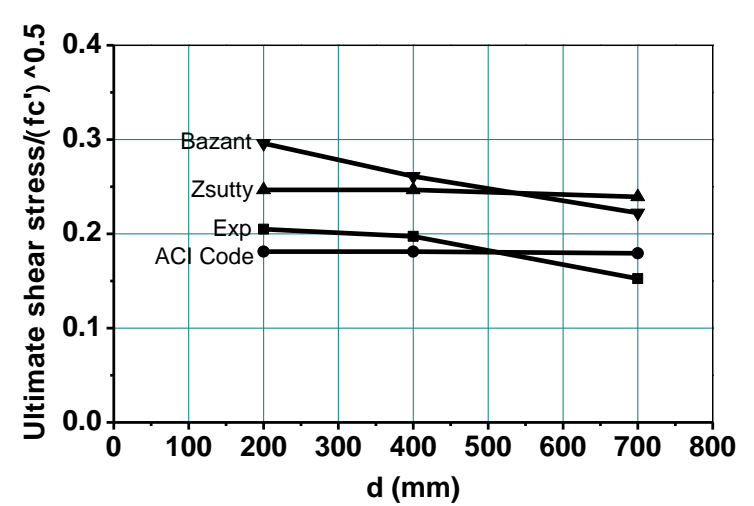

(a) Beams without web reinforcement with $a / d$ of 3.5

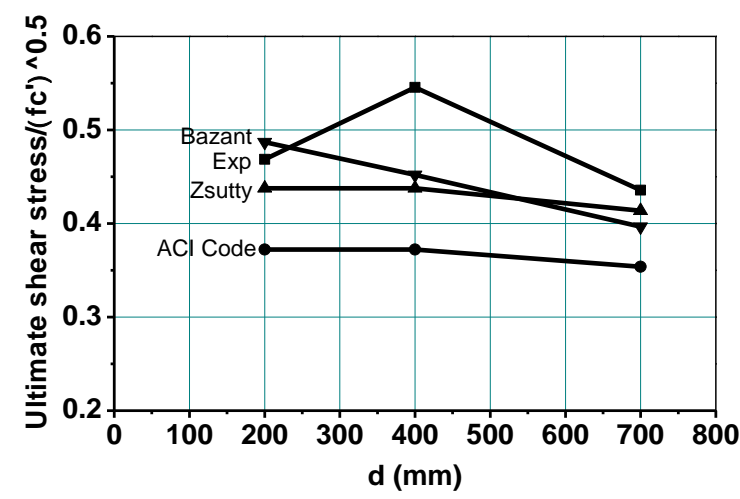

(c) Beams with web reinforcement with $a / d$ of 3.5

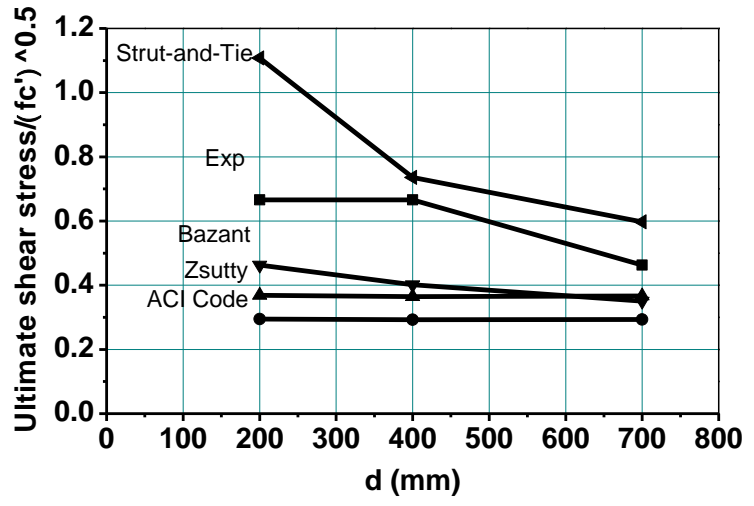

(b)Beams without web reinforcement with ald of 2

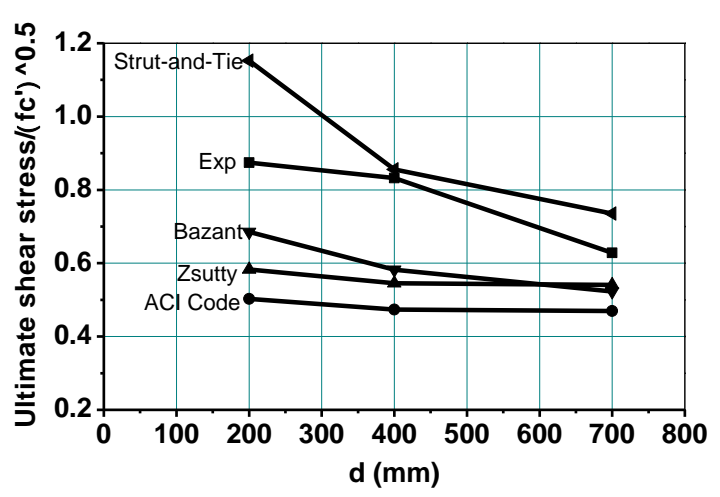

(d) Beams with web reinforcement with a/d of 2

Fig. 11. Comparison of test results with four design methods

Beams with web reinforcement with $a / d=2$, short beams. The prediction in these beams is quit the same to the short beams without web reinforcement with the same $a / d$ ratio.

From above discussion, we can see that Bazant's equation predicts a well trend on the influence of effective $d$ in high-strength concrete slender beams, however, its prediction underestimates the size effect in short beams. Strut-and-Tie model predicts well trend on the influence of effective $d$ in high-strength concrete deep beams, however, its prediction overestimates the ultimate shear stress of all the deep beams. The other methods can not give a good prediction on the influence of the effective depth in this experimental program.

\section{Conclusions}

Compared to normal-strength concrete beams, highstrength concrete beams show more brittle nature in the failure as expected. The shear stress vs. midspan deflection curves obtained from experiment are relatively more linear indicating the more brittle nature of the failure of the high-strength concrete beams. The beams with lower a/d of 2.0 showed higher ultimate shear strength capacity than the beams with $a / d$ of 3.5 due to the arch action. There is more pronounced size effect in large size beams than in small size beams. There is pronounce size effect in short beams than in slender beams, In other words, the shear resistance contributed by arch action shows more size effect than that contributed by beams action. Web reinforcements were effective in restraining the increase of diagonal crack width, therefore reduced the deflection after the formation of the inclined crack. Web reinforcement not only carried shear themselves but also enhanced the strength of the other shear transfer mechanisms. Web reinforcement had no delaying effect in the formation of the first flexural and inclined cracks in concrete beams, but greatly increased the ultimate shear strength. There was no size effect in the shear strength contributed by the web reinforcement. The safety of both ACI Code and Zsutty's equation reduce for the lager size beams. ACI Code is also unsafe for those larger shallow beams without web reinforcement. Bazant's equation is unsafe for the shallow beams without web reinforcement. Strut-and-Tie model predicts well the trend on the influence of effective depth in high-strength concrete deep beams, but it overestimates the shear capacities of all tested deep beams. Bazant's equation predicts well the trend on the influence of effective depth in high-strength concrete slender beams.

\section{REFERENCES}

[1] Kani, G. N. J., 1967. How Safe Are Our Large Reinforced Concrete Beams, ACI Journal, Proceedings, Vol. 64, No. 3, Mar. 1967, pp. 128-141.

[2] Tan, K. H.; and Lu, H. Y., 1999. Shear Behavior of Large Reinforced Concrete Deep Beams and Code Comparisons, 
ACI Structural Journal, Vol. 96, No. 5, Sep.-Oct, pp. 836844.

[3] Walraven, J. C.; and Lehwalter, N., 1994. Size Effects in Short Beams Loaded in Shear. ACI Structural Journal, Vol. 91, No. 5, Sep.-Oct, pp. 585-593.

[4] Taylor, H. P. J. 1972. Shear Strength of Large Beams, Journal of Structural Division, ASCE, Nov, pp. 2473-2490.

[5] Walraven, J. C., 1978. Influence of Member Depth on the Shear Strength of Light Weight Concrete Beams without Shear Reinforcement, Stevin Laboratory Report No. 5-78-4, Delft University of Technology.

[6] Bazant, Z. P.; and Kim, J. K., 1984. Size Effect in Shear Failure of Longitudinally Reinforced Beams, ACI Journal, Proceedings, Vol. 81, No. 5, Sep.-Oct, pp. 456-468.

[7] Bazant, Z. P.; and Sun, H. H., 1987. Size Effect in Diagonal Shear Failure: Influence of Aggregate Size and Stirrups, $A C I$ Material Journal, July-Aug, pp. 259-272.

[8] ACI Committee 318 (1996), Building Code Requirements for Reinforced Concrete (ACI 318-95) and Commentary - ACl 318R-95, American Concrete Institute, Detroit, Michigan.
[9] Zsutty, T. C., "Beam Shear Strength Prediction by Analysis of Existing Data," ACI Journal, V. 65, Nov. 1968, pp. 943-951.

[10] Matamoros, A.B.; and Wong, K. H., 2003. Design of Simply Supported Deep Beams Using Strut-and-Tie Models, ACI Structural Journal, Vol. 100, No. 6, Nov.-Dec. 2003, pp. 704712.

[11] Ahmad, S. H.; Khaloo, A. R.; and Poveda, A., 1986. Shear Capacity of Reinforced High-strength Concrete Beams, ACI Journal, Mar.-Apr, pp. 297-305.

[12] Elzanaty, A. H.; Nilson, A. H.; and Slate, F. O., 1986. Shear capacity of Reinforced Concrete Beams Using High-strength Concrete, ACI Journal, Vol. 83, Mar.-Apr, pp. 290-296.

[13] Foster, S. J.; and Gilbert, R. I., 1998. Experimental Studies on High-Strength Concrete Deep Beams, ACI Structural Journal, Vol. 95, No. 4, July-Aug, pp. 382-390.

[14] Hwang, S. J.; Lu, W. Y.; and Lee, H. J., 2000. Shear Strength Prediction for Deep Beams, ACI Structural Journal, Vol. 97, No. 3, May-June, pp. 367-376. 